\title{
How academic reforms change the organizational design of universities
}

\section{Hagerer, Ilse ${ }^{\text {a }}$}

${ }^{a}$ School of Business Administration and Economics, Osnabrück University, Germany.

\begin{abstract}
The academic landscape is changing in the course of New Public Management (NPM). More duties are assigned to universities and as a result transferred to their faculties. Management knowledge is needed for solving the problem of higher requirements for deans in terms of distribution of resources, responsibility for personal and finances. Until now, deans do not necessarily have this knowledge. One crucial approach for this problem is professionalization, which can take shape in various forms, e. $g$. in establishing positions for a new occupational group of academia professionals. To reach the organization's objective in an effective and efficient way, there is no best solution corresponding to the contingency approach, it rather depends on the framework requirements.

The results of an empiric inquiry of framework requirements and deanery attributes on four German universities show that the infrastructures of the faculties as decentral units depend less on the size of the faculty, but very strong on university's organizational setting. This becomes apparent by the fact that at an elite university with strong research activities and with the profile of an entrepreneurial university, but with small framework requirements in the faculties has established many positions of academia professionals. Smaller universities, but also big multi-discipline universities with scientific excellence don't reach as many academia professionals in spite of having big framework requirements.
\end{abstract}

Keywords: New Public Management; Higher Education Organization; Organizational Design. 


\section{Introduction}

Nowadays higher education systems which are mostly financed by the public are affected by a change of gouvernance structures. There are new mechanisms of regulation based on the concepts of the New Public Management: a model of effective and efficient decision structures. Problems like the reduction of public finances for higher education and higher requirements on the benefit of research and teaching outside of science should be solved this way. (Lange \& Schimank, 2007, p. 523). The ,greatest reform on higher education since decades" (Bundesministerium für Bildung und Forschung [BMBF], 2010) was triggered by abolishing the Hochschulrahmengesetz (Framework Act for Higher Education) in 1998 and the beginning of the Bologna process in 1999 (Scherm, 2012, p. 7), which resulted in the introduction of Europe-wide homogeneous structured degree programs was determined. They should lead to more internationalization, mobility and worldwide attractiveness (Teichler, 2005, p. 81).

From this reforms one might wonder, how universities manage the pressure within this. Until now there is a lack of empirical studies on the implementation and design of the new governance instruments. It is not clear, how far the traditional self-administration model is actually replaced with a new management model (Bogumil, 2013, p. 12). The changes lead to a higher burden for the management of the university, which especially addresses the central and decentral management levels of chairmanship and deanship. Deans must accomplish more and more complex challenges. Therefore there is a gap between the increased profile of qualification and the existing qualifications, which can be closed by establishing positions for academia professionals, a new group of employees working in the field between science, management and administration. The objective of this research is to show organizational solutions for this depending on different framework requirements. Moreover, the effects of the reforms on the situation of the employees are investigated, which gives the problem a special societal relevance.

\section{Foundation}

To get a theoretical foundation for the change caused by these reforms, the 'governance equalizer' is an appropriate analytical instrument. It helps to categorize the change and comparison of governance-regimes close to the state (Schimank, 2007, p. 239). It consists of five dimensions: state regulation, pressure of competition, hierarchic self-regulatory, academic self-organization and external regulation, which represent a typology of governance-regimes related to the higher education sector. The dimension regulation of the state measures characteristics of the public top down regulation. External regulation covers the involvement of external stakeholders, for instance from the industry. Academic selfregulation means the classic functionality of the self-administration of universities with 
their interest in autonomous science. Hierarchic self-organization stands for hierarchies within university like presidents and deans. Especially this dimension forms university into an organization that is capable of acting. Pressure of competition for students, academics, financial resources and reputation predominates within and between universities on quasimarkets by evaluations (Schimank, 2009, p. 125). Pressure of competition, hierarchic selfregulation and external regulation are developed strongly at NPM but weakly at the traditional model, on the contrary academic self-regulation and state-regulation are developed weakly at NPM and strongly at the traditional model (Schimank, 2007, p 242).

The responsibility to implement these reforms was transferred to the universities, so that ability to compete and profile formation shall be facilitated (Hochschulrektorenkonferenz, 2011 , p. 8). The state withdrawal from the micro management leads to a wider autonomy of universities (Lange \& Schimank, 2007, p. 524). This concerns particularly organizational, personal and financial autonomy (Ziegele, 2005, pp. 109-110).

As a new societal requirement this development results in the exploitation of new scopes like selection processes, marketing or quality management. Also the strengthening of institutional management and the introduction of economic management instruments are parts of this profound organizational change (Lange \& Schimank, 2007, pp. 539-541; Blümel, Kloke \& Krücken, 2011, p. 105).

Achievement-oriented public grantings of funds, performance evaluations and rankings are instruments for boosting competition between universities to provide information to prospective students, external capital providers and professors, to strengthen the perception as a complete organization and to produce comparability (Meier, 2009, pp. 160-162). External regulation is effected by external staffed boards like the board of trustees (Hochschulrat), by contractual elements like objective agreements and the impact of accreditation agencies (Meier, 2009, pp. 135-138). The development of the dimensions vary in different countries, e. g. in Great Britain or Australia NPM is pronounced much stronger than in Germany. The traditional German governance system speaks against the conception of universities as actors. Hence there are doubts about their status as an actor, which can be summarized in describing universities more as a loose than a determined organization (Meier, 2009, p. 114). The profound transformation of universities leads to a stronger development as a managing actor with rationalized decision structures (Krücken \& Meier, 2006, p. 241-242).

\section{Method}

The contingency approach as an organizational theory is the basis for this study. For adapting the new needs, universities must be capable of acting more flexible and be 
designed efficiently depending on environmental variables. The contingency approach allows a view on efficient organizational structures depending on situational framework requirements and is therefore suitable for further approaches. As there are no universal efficient organizational structures, organizations must rather adapt their structure to situational framework requirements for being efficient. The interrelation between organizational structure, situational context and success of the organization is interpreted by the fit, which terms the compatibility between variables of structure and situation. That means as much as their coherence concerning specific objectives (Scholz, 1992, para. 543). The ambition of this approach is to explain the attributes of organizational structure by concrete situational framework requirements and to deduce design recommendations so that the organizational structure is assimilated to the situation and the organization is efficient (Kieser, 2006, p. 215). Means to reach that goal are instruments of the empiric-comparative organizational research: the empirical collection of organizational structures and their explanation depending on different situational parameters and the determination of impacts of organizational structures on success (Scherm \& Pietsch, 2007, p. 36).

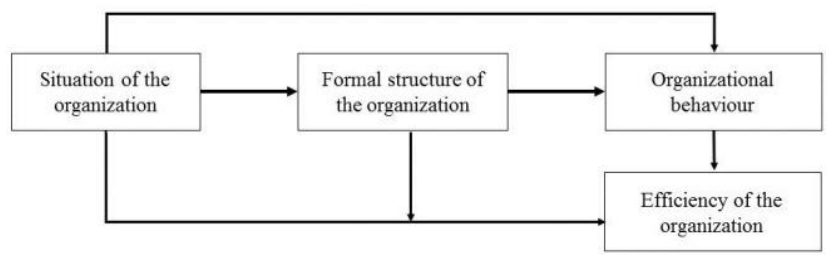

Figure 1. Research program of the contingency approach. Source: Kieser \& Kubicek (1992).

From these four constructs pictured in Figure 1, this work focusses initially on the influence of the situation on organizational structures.

The situational framework requirements of the four selected universities are measured and analyzed. Variables are type of university, profile, size measured in number of students and product mix measured in number of degree programs. The framework requirements of all faculties are measured in number of students and number of degree programs. The attributes of the organizational structure of deaneries are measured using the variables function of dean with the values full time or part time, number of functions of pro-deans, deans of students and deans of research (electoral offices). Relating to the support of academia professionals the type of position, qualification is measured in level of education and finally the number of positions for academia professionals.

The empirical method is a systematic analysis of the homepages of all faculties in the course of a complete survey to find out, which positions are established. The selection of the universities took place within the German state Bavaria in order to get comparability 
regarding the framework requirements and the state law. For a better differentiation 4 of 13 existing universities were chosen that vary in as many values of variables as possible.

Table 1. Chosen universities.

\begin{tabular}{cccccc}
\hline \multicolumn{1}{c}{ LMU } & TU & $\begin{array}{c}\text { University of } \\
\text { Regensburg }\end{array}$ & University of Passau \\
\hline Number of students & $\sim 50000$ & $\sim 33000$ & $\sim 20400$ & $\sim 10000$ \\
$\begin{array}{c}\text { Number of degree } \\
\text { programs }\end{array}$ & 1083 & 182 & 177 & 35 \\
$\begin{array}{c}\text { Number of faculties } \\
\text { Numb }\end{array}$ & 18 & 13 & 11 & 4 \\
\hline
\end{tabular}

Source: own research.

\section{Results}

The Technische Universität München (TUM) and Ludwig-Maximilians-Universität München (LMU) represent universities with scientific excellence. The former has a technical focus, the latter is a multi-discipline university with a big number of students and a wide range of degree programs.

On the contrary University of Passau is small, young and modern having an interdisciplinary, international profile with focus on languages, media and globalization. There are only four faculties. The University of Regensburg stands in the middle as a young, medium-sized multi-discipline university with many degree programs also including natural sciences in contrast to University of Passau.

Regarding LMU it is to state that there is no affinity to many academia professionals. The framework requirements don't seem to influence the number of academia professionals strongly. Faculties with minimal framework requirements also have few academia professionals, but medium-sized or large faculties bring few or medium number of electoral offices and of academia professionals as well. It is conspicuous that most faculties of LMU have a dean of research, which deals with tasks correspondent to the strong research profile.

At the faculties of TUM, which has strong research activities and the profile of an entrepreneurial university, already small framework requirements on the faculties lead to many positions of academia professionals. In opposition to the LMU there is no dean of research in any faculty. Considering the large amount of academia professionals, that could mean that they manage the respective tasks.

The medium-sized University of Regensburg is equipped with a medium number of academia professionals and electoral offices. 
At the University of Passau the number of academia professionals never becomes big independent of the faculty related framework requirements, but the number is small, if the framework requirements are minimal. The four faculties have no dean of research, which leads to the conclusion that the profile in research competition is minor.

The values of variables from respectively two faculties of each university, which are particularely demonstrative, are pictured in Table 1 .

Table 2. Results of exemplary faculty related framework requirements and attributes of deaneries

\begin{tabular}{|c|c|c|}
\hline LMU & Psychology & Biology \\
\hline Number of students & 10397 & 1901 \\
\hline Number of degree programs & 27 & 8 \\
\hline Number of pro-deans & 1 & 1 \\
\hline Number of deans of students & 1 & 1 \\
\hline Number of deans of research & 1 & - \\
\hline $\begin{array}{l}\text { Number of positions for } \\
\text { academia professionals }\end{array}$ & 1 & 1 \\
\hline TUM & Sport Science & Architecture \\
\hline Number of students & 1640 & 1234 \\
\hline Number of degree programs & 5 & 8 \\
\hline Number of pro-deans & 1 & 1 \\
\hline Number of deans of students & 2 & 1 \\
\hline Number of deans of research & - & - \\
\hline $\begin{array}{l}\text { Number of positions for } \\
\text { academia professionals }\end{array}$ & 32 & 12 \\
\hline University of Regensburg & $\begin{array}{c}\text { Philology, } \\
\text { Literary Studies, } \\
\text { Cultural Science }\end{array}$ & Mathematics \\
\hline Number of students & 3877 & 239 \\
\hline Number of degree programs & 39 & 3 \\
\hline Number of pro-deans & 1 & 1 \\
\hline Number of deans of students & 1 & 1 \\
\hline Number of deans of research & 1 & 1 \\
\hline $\begin{array}{l}\text { Number of positions for } \\
\text { academia professionals }\end{array}$ & 4 & 5 \\
\hline University of Passau & Philosophy & $\begin{array}{l}\text { Informatics and } \\
\text { Mathematics }\end{array}$ \\
\hline Number of students & 5783 & 469 \\
\hline
\end{tabular}




$\begin{array}{ccc}\text { Number of degree programs } & 24 & 4 \\ \text { Number of pro-deans } & 1 & 1 \\ \text { Number of deans of students } & 1 & 1 \\ \text { Number of deans of research } & - & - \\ \text { Number of positions for } & 5 & 3 \\ \text { academia professionals } & & \end{array}$

\section{Conclusion}

The results of the empiric inquiry of framework requirements and deanery attributes show that by trend the infrastructure of the faculties as decentral units depends less on the size of the faculty, but very strong on the organizational setting of the university.

Especially at the LMU with the largest offer of study courses and the largest amount of students but not maximum positions for academia professionals, the divergency between framework requirements and deanery attributes is striking.

These investigations pose the question, if design recommendations can be given according to an ideal deanery-situation-fit. The organizational attributes of deaneries should be optimally harmonized to allow a better deanery-situation-fit. Maximum framework requirements of university and faculty should determine a maximum amount of positions for academia professionals, so that they lead to organizational success.

There is no fit at Bavarian universities so far. The contingency approach says that the TUM with maximum deanery attributes must have the best organizational success, which means to fulfill the core processes better than LMU, because here is a bigger fit.

Do organizations design the best structures by themselves? Or is it possible that the predominant typologies do not optimally fit to the environmental requirements? Align universities themselves accordingly to their specific situation up to their core processes? Or has the assimilation process only points of contact to the administrative frontage? Is a more effective and efficient university possible by using an adequate organizational design?

It has to be investigated if universities can better adapt themselves to their environment by an adequate organizational design and fulfill their state as an actor in a better way.

\section{References}

Blümel, A., Kloke, K., \& Krücken, G. (2011). Professionalisierungsprozesse im Hochschulmanagement in Deutschland. In A. Langer \& A. Schröer (Eds.), Professionalisierung im Nonprofit-Management (pp. 105-127). Wiesbaden: VS. 
Bogumil, J., Burgi, M., Heinze, R. G., Gerber, S., Gräf, I.-D., Jochheim, L., Schickentanz, M., \& Wannlöffel, M. (2013). Modernisierung der Universitäten - Umsetzungsstand und Wirkungen neuer Steuerungsinstrumente, Berlin: Edition Sigma.

Bundesministerium für Bildung und Forschung [BMBF]. (2012). Der Bologna-Prozess. Retrieved from http://www.bmbf.de/de/3336.php, 24.01.2016

Hochschulrektorenkonferenz (HRK). (2011). Zur Hochschulautonomie, Entschließung der 10. Mitgliederversammlung am 03.05.2011, Bonn. Retrieved from http://www.hrk.de/uploads/media/Entschl._HS-Autonomie_Endfassung_MV_10.pdf

Kieser, A. (2006). Der situative Ansatz. In A. Kieser \& M. Ebers (Eds.), Organisationstheorien (6th ed., pp. 215-246). Stuttgart: Kohlhammer.

Kieser, A., \& Kubicek, H. (1992). Organisation ( $3^{\text {rd }}$ ed.). Berlin, New York: de Gruyter.

Krücken, G., \& Meier, F. (2006). Turning the University into an Organizational Actor. In G. S. Drori, J. W. Meyer \& H. Hwang (Eds.), Globalization and Organization (pp. 241257). Oxford: Oxford University Press.

Lange, S., \& Schimank, U. (2007). Zwischen Konvergenz und Pfadabhängigkeit: New Public Management in den Hochschulsystemen fünf ausgewählter OECD-Länder. In K. Holzinger, H. Jörgens \& C. Knill, (Eds.), Transfer, Diffusion und Konvergenz von Politiken, Politische Vierteljahresschrift, Sonderheft (38/2007), (pp. 522-548). Wiesbaden: VS.

Meier, F. (2009). Die Universität als Akteur. Zum institutionellen Wandel in der Hochschulorganisation. Wiesbaden: VS.

Scherm, E. (2012). Von der Hochschulreform zur „unternehmerischen“ Universität: ein weiter Weg. Das Hochschulwesen, 60 (1/2012), 7-12.

Scherm, E., \& Pietsch, G. (2007). Organisation - Theorie, Gestaltung, Wandel. München: Oldenbourg.

Schimank, U. (2007). Die Governance-Perspektive: Analytisches Potenzial und anstehende konzeptionelle Fragen. In H. Altrichter, T. Brüsemeister, Thomas \& J. Wissinger (Eds.), Educational Governance - Handlungskoordination und Steuerung im Bildungssystem (pp. 232-260). Wiesbaden: VS.

Schimank, U. (2009). Governance-Reformen nationaler Hochschulsysteme. In: J. Bogumil \& R. G. Heinze (Eds.), Neue Steuerung von Hochschulen (pp. 123-137). Berlin: Edition Sigma.

Scholz, C. (1992). Effektivität und Effizienz, organisatorische. In E. Frese (Ed.), Handwörterbuch der Organisation (3rd ed., para. 534-552). Stuttgart: SchäfferPoeschel.

Teichler, U. (2005). Hochschulstrukturen im Umbruch, Frankfurt am Main, New York: Campus.

Ziegele, F. (2005). Die Umsetzung von neuen Steuerungsmodellen (NSM) im Hochschulrecht. In: R. Fisch \& S. Koch (Eds.), Neue Steuerung von Bildung und Wissenschaft (pp. 107-121). Bonn: Lemmens. 